\title{
Chemotaxis Towards Aromatic Compounds: Insights from Comamonas testosteroni
}

\author{
Yun-Hao Wang ${ }^{1,2}$, Zhou Huang ${ }^{1}$ and Shuang-Jiang Liu ${ }^{1,2, *}$ \\ 1 State Key Laboratory of Microbial Resources and Environmental Microbiology Research Center, Institute of \\ Microbiology, Chinese Academy of Sciences, Beijing 100101, China; wangyunhao_123@yeah.net (Y.-H.W.); \\ huangzhou_129@msn.com (Z.H.) \\ 2 University of Chinese Academy of Sciences, Beijing 101408, China \\ * Correspondence: liusj@im.ac.cn; Tel.: +86-10-64807423
}

Received: 21 April 2019; Accepted: 30 May 2019; Published: 1 June 2019

check for updates

\begin{abstract}
Chemotaxis is an important physiological adaptation that allows many motile bacteria to orientate themselves for better niche adaptation. Chemotaxis is best understood in Escherichia coli. Other representative bacteria, such as Rhodobacter sphaeroides, Pseudomonas species, Helicobacter pylori, and Bacillus subtilis, also have been deeply studied and systemically summarized. These bacteria belong to $\alpha-, \gamma-, \varepsilon$-Proteobacteria, or Firmicutes. However, $\beta$-Proteobacteria, of which many members have been identified as holding chemotactic pathways, lack a summary of chemotaxis. Comamonas testosteroni, belonging to $\beta$-Proteobacteria, grows with and chemotactically responds to a range of aromatic compounds. This paper summarizes the latest research on chemotaxis towards aromatic compounds, mainly from investigations of $C$. testosteroni and other Comamonas species.
\end{abstract}

Keywords: Comamonas testosteroni; chemoreceptor; chemotaxis; aromatic compounds

\section{Introduction}

Aromatic compounds have one or more aromatic rings containing resonance bonds, which make them chemically inert due to charge distribution over the whole skeleton of the aromatic ring. It has been estimated that about $25 \%$ of photosynthetic products from plants are deposited as lignin, which is one of the most abundant aromatic compounds on earth [1,2]. Other biogenic aromatic compounds, such as phenylalanine, tyrosine, tryptophan, many hormones, and signal molecules, play important roles in the maintenance and regulation of biological processes. Chemically synthesized aromatic compounds are important raw materials. Benzene, phenol, and toluene are classified as priority pollutants [3]. The toxicity and mutagenicity of nitroaromatic compounds have been documented $[4,5]$.

Microbial biodegradation is an important process for removal of aromatic pollutants from environments [6,7]. In addition to metabolic robustness, microbial degradation also relies on the bioavailability of aromatic pollutants. Bacterial chemotactic responses toward aromatic compounds have attracted extensive interest [8-10] and are beneficial for bacteria to find more friendly environments and to degrade pollutants [11-13]. Chemotaxis may also facilitate the transfer of catabolic genes via motile bacteria to contaminated environments [14], thus promoting the coexistence of biodegradation and chemotaxis genes. Reviews are available on bacterial chemotaxis regarding stimulus-sensing and signal-processing [15], on exploring the function of bacterial chemotaxis [16], and on Pseudomonas chemotaxis [17]. This review is focused on the recent progress made on the study of bacterial chemotaxis towards aromatic compounds, in particular with Comamonas testosteroni. 


\section{The Taxonomy, Ecology, Physiology, and Chemotaxis of C. testosteroni}

C. testosteroni belongs to the genus Comamonas that has 21 species (http://www.bacterio. net/comamonas.html) (Figure 1). The Comamonas species are Gram-negative bacteria belong to $\beta$-Proteobacteria, and are distributed widely in soil, sediments, and garden ponds [18-20]. Based on the IMG database (https://img.jgi.doe.gov/), 11 of the 21 Comamonas species have been genome-sequenced [21], and mining these genomes indicated that the key genes for hexose phosphorylation were missing [22]. Thus, unlike Pseudomonas species that prefer to assimilate carbohydrates for growth, the Comamonas species do not use glucose as a sole carbon source, but grow well with non-sugar carbon sources such as organic acids and aromatic compounds. Although Comamonas and Pseudomonas species are different in carbohydrate assimilation, they share similar ecological habitats, and both are able to metabolize aromatic compounds. Studies have demonstrated that Comamonas species play an important role in the biological geocycling of nutrients in environments [23-25], as well as in bioremediation of polluted environments [26-28]. A search on Web of Science using the key word "Comamonas" revealed more than 1700 publications from 2000 to 2018, and citation of these publication has increased sharply in recent years, which suggests a growing interest from scientists. The $C$. testosteroni strain CNB-1 was isolated from activated sludge and grows using chloronitrobenzene as carbon and nitrogen sources [29]; it has been exploited for the bioremediation of chloronitrobenzene-polluted soil [30]. The genes involved in the degradation of chloronitrobeneze were located on a mega-plasmid pCNB1 [31], and the degradation pathway was identified [32]. Another strain of $C$. testosteroni, CNB-2, is a derivative from strain CNB-1 from which pCNB1 was cured [33].

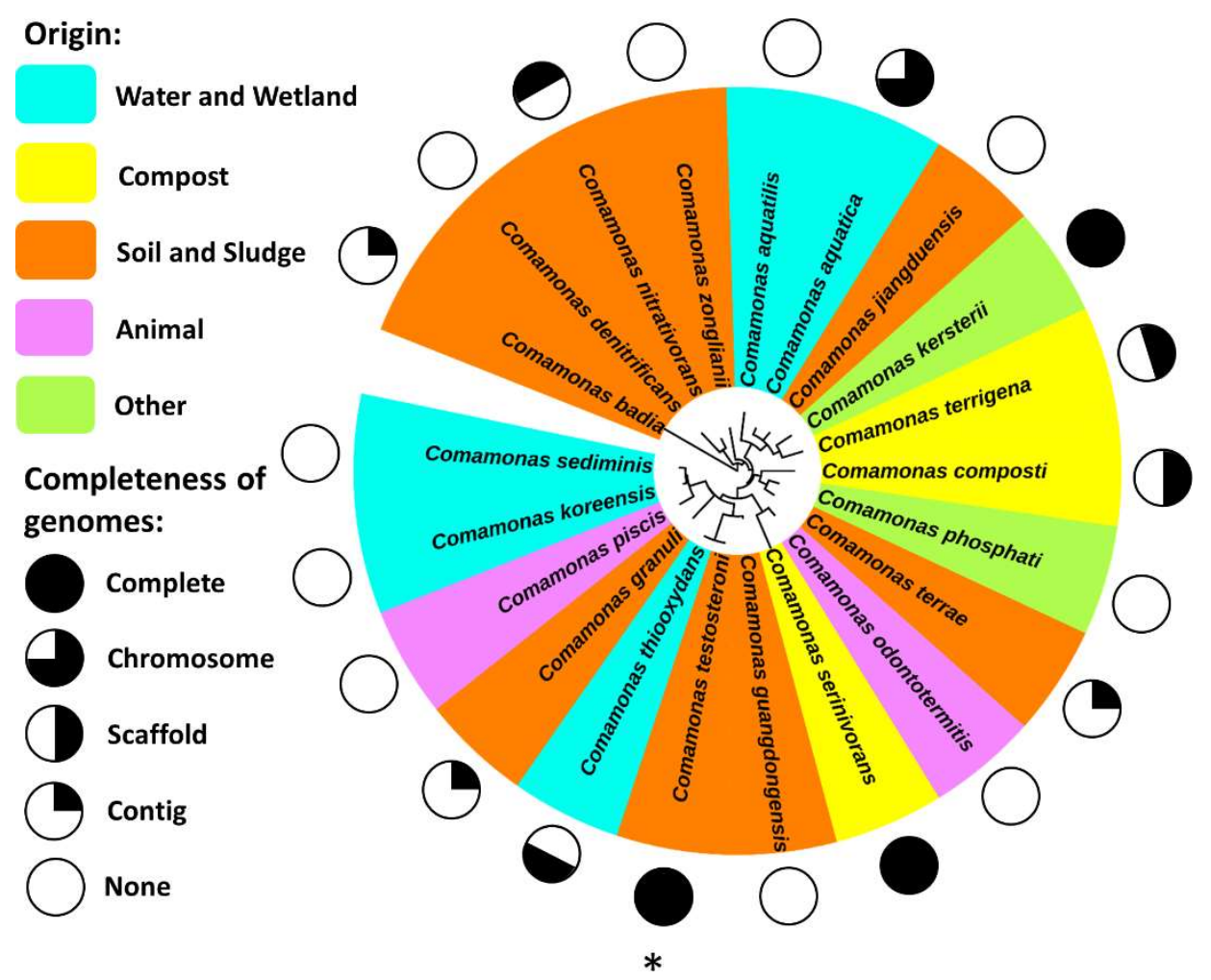

Figure 1. The genus Comamonas: phylogeny, diversity, habitats, and genomes. The phylogenetic analysis is based on $16 \mathrm{~S}$ rRNA genes. Background colors represent the origins of type strains of species. The completeness of genomes is indicated by circles outside the species names. Comamonas testosteroni is indicated by an asterisk $\left(^{*}\right)$.

Bacterial chemotaxis is the movement of cells with either flagella, pili, or gliding structures in response to chemical gradients. The well-studied enteric Escherichia coli has only one gene cluster and 
five chemoreceptors for chemotaxis. However, many environmental bacteria have more gene clusters and chemoreceptors. Studies show that the number of chemoreceptors in genomes is relevant to lifestyles, but not to genome sizes [34]. C. testosteroni strain CNB-1 is motile with 1-3 polar flagella and chemotactically responds to a range of aromatic and other organic compounds (Table 1). In contrast to E. coli, data-mining of the CNB-1 strain genome revealed two chemotaxis-like gene clusters and 19 putative chemoreceptor genes.

Table 1. Summary of the chemotactic responses of Comamonas species to various organic compounds.

\begin{tabular}{|c|c|c|c|}
\hline Strain & \multicolumn{2}{|c|}{ Potential Chemoeffector } & Refs \\
\hline Comamonas sp. strain JS765 & 2-nitrotoluene & & [35] \\
\hline $\begin{array}{l}\text { Comamonas testosteroni } \\
\text { strain CNB-1 }\end{array}$ & $\begin{array}{l}\text { benzoate } \\
\text { 3-hydroxybenzoate } \\
\text { 2,6-dihydroxybenzoate } \\
\text { vanillic acid } \\
\text { gallic acid } \\
\text { phenol } \\
\text { adipate } \\
\text { fumarate } \\
\text { citrate } \\
\alpha \text {-ketoglutarate } \\
\text { oxaloacetate }\end{array}$ & $\begin{array}{l}\text { 2-hydroxybenzoate } \\
\text { 4-hydroxybenzoate } \\
\text { protocatechuate } \\
\text { vanillin } \\
\text { gentisate } \\
\text { catechol } \\
\text { succinate } \\
\text { pyruvate } \\
\text { malate } \\
\text { cis-aconitate } \\
\text { isocitrate }\end{array}$ & {$[36-38]$} \\
\hline $\begin{array}{c}\text { Comamonas testosteroni } \\
\text { ATCC } 11996\end{array}$ & $\begin{array}{l}\text { 1-dehydrotestosterone } \\
17 \alpha \text {-hydroxyprogesterone } \\
11 \alpha \text {-hydroxyprogesterone } \\
21 \alpha \text {-hydroxyprogesterone } \\
5 \text {-androsten-3 } \beta \text {-17 } \beta \text {-diol }\end{array}$ & $\begin{array}{l}\text { pregnenolone } \\
\text { androstanedione } \\
\text { testosterone } \\
\text { deoxycorticosterone }\end{array}$ & [39] \\
\hline
\end{tabular}

\section{Chemoreceptors of $C$. testosteroni}

According to the well-studied enteric bacteria E. coli and Salmonella enterica, typical chemotactic responses start with signals generated by transmembrane chemoreceptors, also called methyl-accepting chemotaxis proteins (MCPs). Upon conformational changes of chemoreceptors, the phosphotransfer starts from histidine kinase CheA to response regulator CheY [15]. Phosphorylated CheY interacts with the flagellar switch protein FliM and, as a result, reverses flagellar rotation [40]. The chemotactic proteins phosphatase CheZ [41], methyltransferase CheR [42], and methylesterase CheB [43] contribute to signal termination and adaptation. C. testosteroni has a dozen predicted chemoreceptors, one histidine kinase, two response regulators, and also has phosphorylation and methylation systems.

\subsection{Genomic Data-mining of Chemoreceptor Genes}

Analysis of the C. testosteroni CNB-1 genome using the MiST.2 database [44] revealed 19 chemoreceptor genes. The putative chemoreceptor genes of other Comamonas genomes were also explored. For example, C. kerstersii has 25 and C. aquatic 35 chemoreceptor genes. Surprisingly, C. serinivorans has only one chemoreceptor gene on its entire genome. It would be interesting to know how this bacterium senses and responds to different environmental signals in the environment.

\subsection{Classification of Chemoreceptors from C. testosteroni CNB-1}

Based on signaling domain sequences in chemoreceptors, the predicted nineteen chemoreceptors of strain CNB-1 belong to two major classes, $40 \mathrm{H}$ and $36 \mathrm{H}$ (Figure 2) [45]. Seventeen of the nineteen chemoreceptors are assigned to the $36 \mathrm{H}$ class. Members of the $36 \mathrm{H}$ class chemoreceptors are known to interact with the chemotaxis signal transduction class F7 [46,47]. The 36H chemoreceptors MCP2201, MCP2983, and MCP2901 from C. testosteroni CNB-1 were experimentally shown to be involved in chemotaxis towards di- and tricarboxylic acids and aromatic compounds [36-38]. The only $40 \mathrm{H}$ class 
chemoreceptor MCP3986 has recently been identified to be involved in biofilm formation [48]. The last chemoreceptor, MCP0846, does not match confidently to any classes (Figure 2).

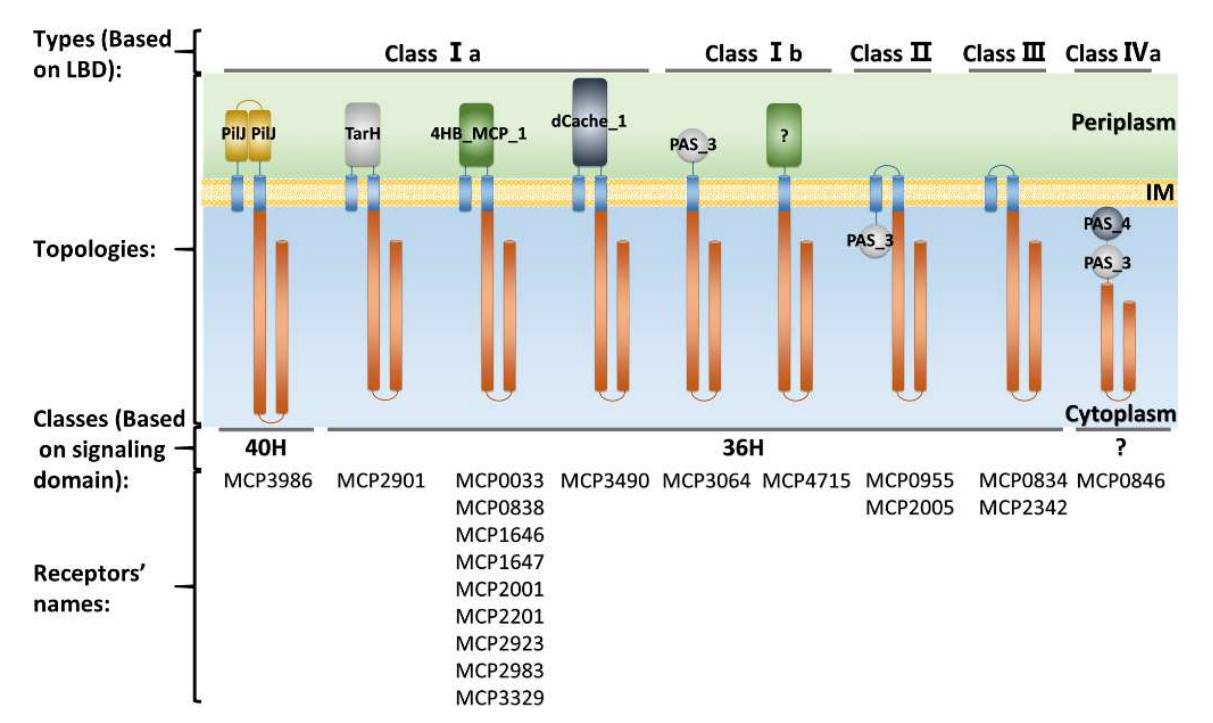

Figure 2. The chemoreceptor repertoires of C. testosteroni CNB-1 and their classification. Domain architecture of chemoreceptors was identified by using CDvist [49].

Besides the signaling domain, the ligand-binding domain (LBD) that senses environmental stimuli is also used for chemoreceptor classification. Wuichet et al. [50] classified chemoreceptors according to their topologies into four classes (I-IV). Lacal et al. [51] further distinguished class I as two subclasses, according to the number of transmembrane (TM) regions of chemoreceptors. The class IV chemoreceptors can also be divided into two subclasses according to the presence or the absence of LBDs [51]. As shown in Figure 2, the most abundant topology in C. testosteroni CNB-1 is class I chemoreceptors that harbor pericytoplasmic LBDs: 12 chemoreceptors belong to class Ia and two chemoreceptors belong to class 1b. MCP2005 and MCP0955, both containing a cytoplasmic PAS domain, belong to class II topology. MCP0834 and MCP2342 have one or two TM regions but no LBDs, so they can be assigned to class III topology. Their functions in chemotactic sensory are still unknown. MCP0846 has a class IVa topology with two PAS domains and no TM helices (Figure 2).

\section{Functional Identification of Chemoreceptors from C. testosteroni}

\subsection{Bioinformatic Prediction of Potential Ligand-Binding Domains}

The LBD sequences are more divergent compared with the signaling domains of chemoreceptors. According to Ortega et al. [52], more than 80 different LBD types were found in the Pfam 31.0 database. As shown in Figure 2, there are 10 chemoreceptors equipped with LBDs composed of 4-helix bundles (4HB_MCP_1 and TarH) in CNB-1. There are four chemoreceptors containing PAS domains: MCP0846, MCP0955, MCP2005, and MCP3064 (Figure 2). The chemoreceptors MCP3490 and MCP3986 contain dCache and PilJ domains, respectively (Figure 2). The LBD of MCP4715 is an unknown LBD type (Figure 2). There is no LBD identified in MCP0834 and MCP2342 (Figure 2), which raised the question as to how they sense stimulating signals. The diversity of LBDs is the structural basis for chemoreceptors to recognize diverse environmental signals. Meanwhile, this diversity also resulted in the complexity and difficulty of LBDs functional annotation, although a variety of ways to annotate them have been introduced [53].

\subsection{Functional Redundancy of Chemoreceptors}

Recent studies have shown functional redundancy of chemoreceptors in P. aeruginosa [54] and other bacteria $[55,56]$. In C. testosteroni CNB-1, the 19 putative chemoreceptors were individually 
disrupted, and the resulting mutants were tested for chemotaxis towards aromatic and other organic compounds with semisoft agar plate assays. Results showed that none of these mutants completely lost chemotactic responses to the tested compounds, although several mutants showed weakened chemotactic responses. These observations indicated that the chemoreceptors in $C$. testosteroni were likely to be functionally overlapping or redundant. A chemoreceptor-null mutant CNB-1 $\triangle 20$ was created by deletion of all 19 chemoreceptor genes (this mutant was named CNB- $1 \Delta 20$ because the gene MCP2901 was deleted two times). As expected, this mutant CNB-1 $\Delta 20$ completely lost its chemotactic responses. With this chemoreceptor-null mutant CNB-1 $\Delta 20$, we were able to identify the functional redundancy of chemoreceptors in C. testosteroni via complementation of individual chemoreceptor genes. All three chemoreceptors MCP2201, MCP2901, and MCP2983 were able to trigger metabolism-dependent chemotaxis towards aromatic compounds, although they have different ligand-binding spectra: MCP2201 binds to oxaloacetate, citrate, cis-aconitate, isocitrate, $\alpha$-ketoglutarate, succinate, fumarate, and malate [36]; MCP2983 only binds to cis-aconitate [37]; and MCP2901 binds to citrate, as well as to aromatic molecules such as gentisate, 4-hydroxybenzoate, 2,6-dihydroxybenzoate, and 2-hydroxybenzoate [38]. The advent of the MCP-null mutant CNB-1 $\Delta 20$ is critical to overcome functional redundancy of chemoreceptors, and this mutant CNB- $1 \Delta 20$ can be used to identify chemoreceptors from other bacteria.

\section{Chemotaxis of C. testosteroni Towards Aromatic Compounds}

Chemotaxis towards aromatic compounds has been widely documented for various bacteria, including members of Pseudomonas [9,14], Acidovorax [35], Ralstonia [57,58], Agrobacterium [59], Azospirillum [60], Bradyrhizobium, and Rhizobium [61]. C. testosteroni grows with a variety of aromatic compounds, and many of these compounds also serve as chemotactic attractants. Both metabolism-dependent and metabolism-independent chemotaxis, as defined by Pandey and Jain [62], have been reported for $C$. testosteroni $[36,38]$. The well-known metabolism-dependent chemotaxis of aromatic compounds is Aer-like chemoreceptors mediated chemotaxis. The PAS domains of Aer-like chemoreceptors are able to sense the concentrations of FAD molecules during metabolism of compounds. It was demonstrated that Aer2 [63] and three other polar localized Aer-like proteins [64] triggered chemotaxis of P. putida towards (methyl)phenols and phenylacetic acid. Acidovorax species also uses an Aer chemoreceptor for taxis towards 2-nitrotoluene [35]. C. testosteroni CNB-1 has four Aer-like chemoreceptors (MCP0846, MCP0955, MCP2005, and MCP3064) with PAS domains, which have tryptophan as a specific recognition site of FAD [65]. MCP0955, MCP2005, and MCP3064 have typical transmembrane regions and are predicted to be membrane-located, while MCP0846 does not have transmembrane regions and is predicted to be a cytoplasmic chemoreceptor. Although the functions of these chemoreceptors have not been experimentally identified, their functions presumably are the same as other Aer-like chemoreceptors (Figure 3). 


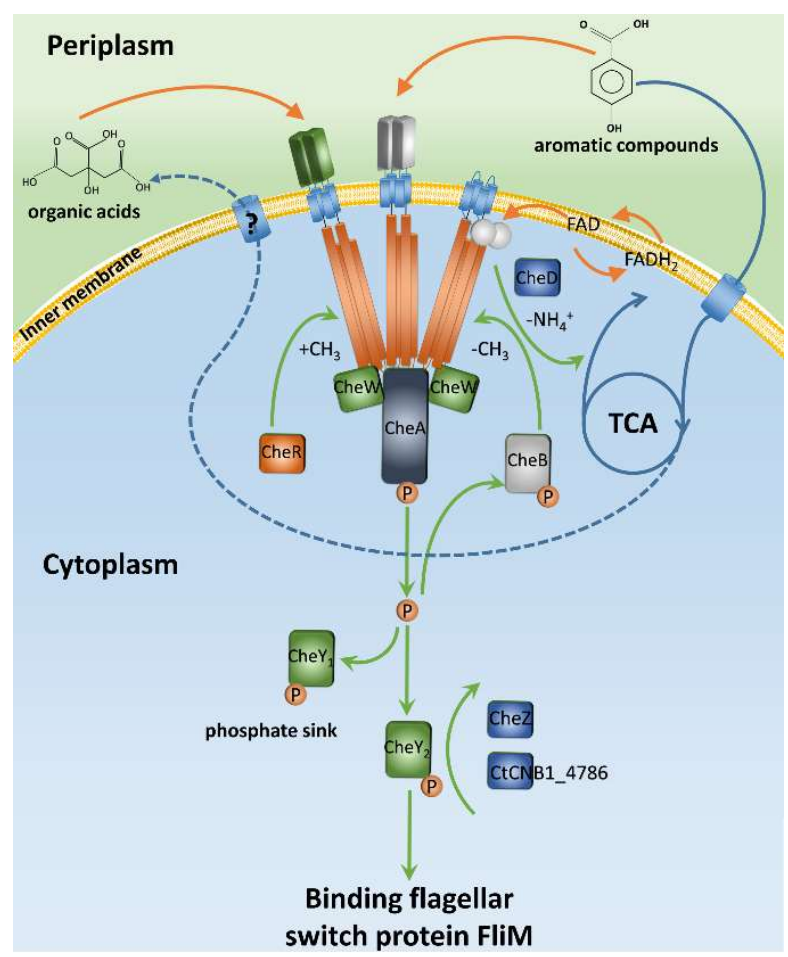

Figure 3. The Comamonas testosteroni CNB-1 chemotaxis pathway. Both metabolism-dependent and -independent chemotaxis exist in CNB-1 simultaneously. Some chemoreceptors directly sense aromatic compounds, and others sense metabolic intermediates or energy levels. The dotted line indicates a postulate pathway of material transportation.

Besides the Aer-like chemoreceptors that sense FAD molecule, recent studies have demonstrated that other chemoreceptors trigger chemotaxis towards aromatic compounds via sensing intermediate metabolites [36-38]. The chemoreceptors MCP2201 and MCP2983 from C. testosteroni mediated chemotaxis towards aromatic compounds via binding to citrate, cis-aconitate, succinate, and other molecules of Kreb's cycle when grows with aromatic compounds (Figure 3) [36,37]. Chemoreceptors that bind to and sense Kreb's cycle intermediates were reported in other bacteria such as P. aeruginosa, P. putida, and Salmonella typhimurium [66-68]. One of these chemoreceptors, TcpS, was able to trigger chemotaxis towards aromatic compounds when it was complemented into C. testosteroni $\Delta 20$ [36]. Evolution of metabolism-dependent chemotaxis towards aromatic compounds may occur widely in microbes, and it is a shrewd strategy. This strategy converges a wide variety of substances into a few metabolic intermediates (including FAD) as chemoeffectors, so it would reduce the variety of chemoreceptors and save energy. Metabolism-independent chemotaxis was also reported, and chemoreceptors that were putatively binding directly to aromatic compounds were proposed. The chemoreceptor NahY from P. putida triggered chemotaxis towards naphthalene [69,70], and the chemoreceptor $\mathrm{NbaY}$ of $P$. fluorescens triggered chemotaxis towards 2-nitrobenzoate [71]. Moreover, the McpT of P. putida DOT-T1E and CtpL of P. aeruginosa PAO1 reportedly trigger chemotactic responses to toluene, 4-chloroaniline, and catechol $[72,73]$. However, the ligand-binding properties of those chemoreceptors were not demonstrated. Recently, studies reported that the McpP from P. putida bound $\mathrm{C} 2$ and $\mathrm{C} 3$ carboxylic acids, which had been proposed being a chemoreceptor for benzoate. McpP is homologeous to $\mathrm{NbaY}$, and investigation showed that neither McpP nor NbaY bound to benzoate, nitrobenzoate, or other substituted benzoates [74]. The first biochemical evidence that demonstrated a chemoreceptor directly bound to aromatic compounds was from C. testosteroni: MCP2901 binds to 2,6-dihydroxybenzoate and 2-hydroxybenzoate and triggers signal transduction for chemotaxis (Figure 3) [38]. So far, the other known chemoreceptor that binds to aromatic compounds is the PcaY for protocatechuate from P. putida KT2440 [75]. We have also biochemically characterized PcaY from 
P. putida F1, and its ligand is also protocatechuate. Compared to metabolism-dependent chemotaxis, metabolism-independent chemotaxis enables microbes to have a faster response and improves the chances of survival. For some non-metabolizable substances such as toxic compounds and metal, metabolism-independent chemotaxis is the only choice.

\section{Chemotactic Signaling Pathways in C. testosteroni and Other Comamonas Species}

So far, the chemosensory signaling pathway in enteric E. coli has been extensively characterized [76,77]. However, environmental bacteria often have more complex chemotactic signaling systems $[15,78]$ than does E. coli. Based on genome data-mining, half of chemotactic bacteria of which genomes have been sequenced have more than one CheAs [46]. Besides phosphatases CheZ, CheC, FliY, and CheX also have dephosphorylation activities for CheY-P [79]. In addition, other chemotactic proteins have been found: CheD has deamination activity for key glutamine residues of chemoreceptors. $\mathrm{CheV}$, a CheW-like coupling protein, is a scaffold between CheA and chemoreceptors [80]. These genetic organizations of chemotactic genes in environmental bacteria are more complex than in enteric E. coli. Bacteria such as R. sphaeroides, B. subtilis, and P. aeruginosa have additional gene clusters, and those clusters are similar to the che cluster [81]. Most of these additional clusters are involved in modulation of chemotaxis [82,83], but some of them are involved in the control of alternative biological behavior, including twitching motility [84], biofilm formation [85], cell development [86], and flagellar biosynthesis [87]. In C. testosteroni CNB-1, there are che and che-like clusters, respectively (Figure 4). The che cluster contains a complete set of chemotaxis genes, and is essential for chemotaxis. Compared to that of E. coli, the che cluster of C. testosteroni CNB-1 has two CheYs. The CheY ${ }_{2}$ is FliM-binding and is the true chemotaxis response regulator in CNB-1. The function of $\mathrm{CheY}_{1}$ is a phosphate sink [48]. In addition to the phosphatase CheZ on the che cluster, we have recently identified an additional gene (CtCNB_4786) that showed low sequence identity to CheZ but is involved in chemotactic signal quenching (unpublished data). The che-like gene cluster regulates biofilm formation, and was recently named $f l m$ cluster. Cross-talk between che and $f l m$ clusters via phosphotransfer was identified, and coordination of chemotaxis and biofilm formation was proposed [48].

With this knowledge of $C$. testosteroni, we explored other Comamonas genomes for che and che-like gene clusters (Figure 4). We found that nine of the 11 Comamonas genomes have che clusters, and they have consistent components and similar genetic organization to the che cluster of $C$. testosteroni CNB-1. We also found that six of the 11 Comamonas genomes have gene clusters similar to the $\mathrm{flm}$ cluster of $C$. testossteroni CNB-1, suggesting that coordination of chemotaxis and biofilm formation might occur also in other Comamonas species. Interestingly, we observed that some of the che-like clusters of C. badia and C. granuli have annotated pilTs, of which the production is a Tfp pilus assembly protein and can regulate twitching motility, and other components are consistent with the flm cluster. Some additional che-like clusters that have different genetic organization to $C$. testosteroni CNB-1 clusters were observed in C. granuli and C. aquatica genomes, respectively (Figure 4). So far, the functions of these additional che-like clusters are still unknown. 


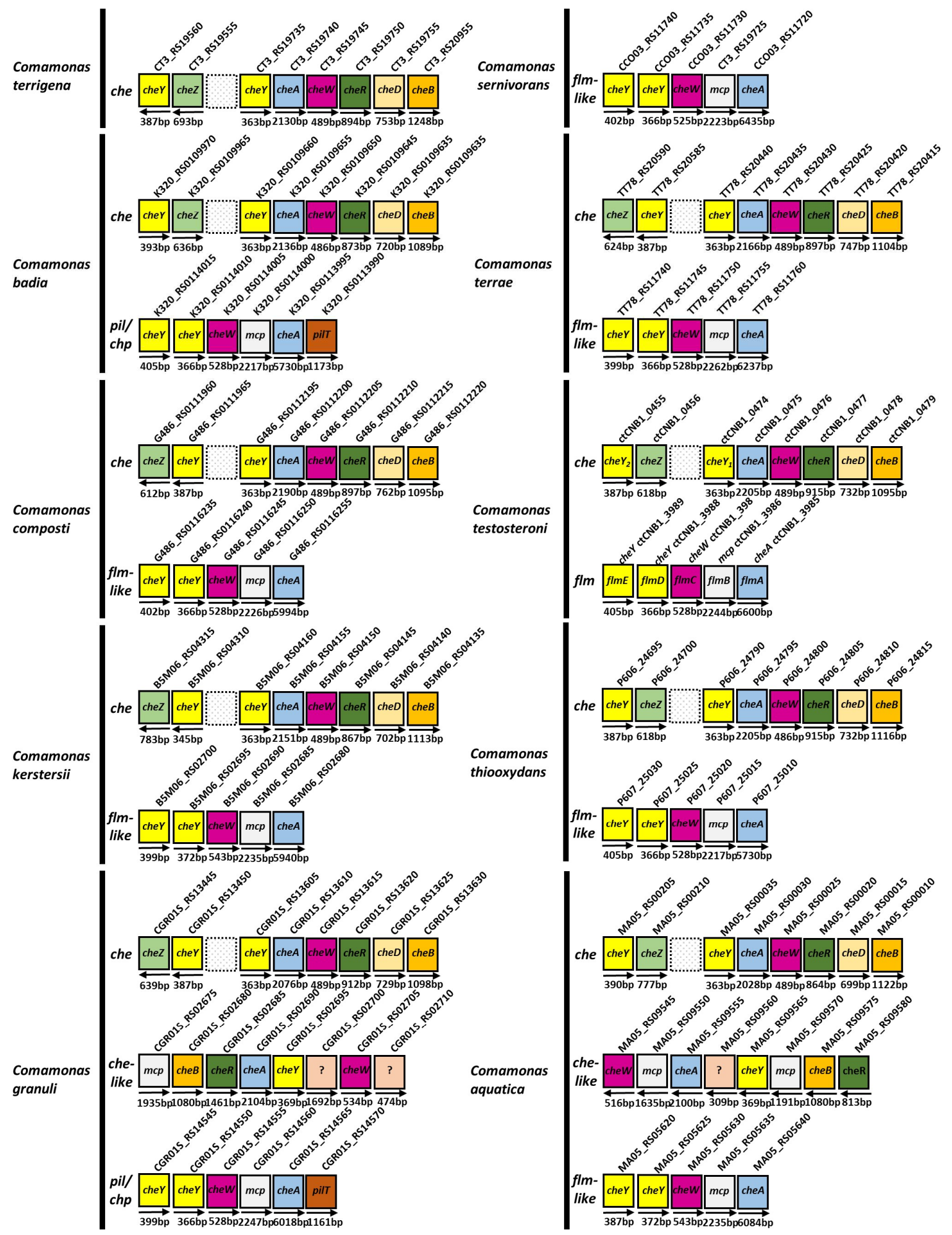

Figure 4. Data-mining of che and che-like gene clusters in C. testosteroni and other Comamonas genomes. There are in total 11 Comamonas genomes in publically available databases. Except for C. nitrativorans (IMG Genome ID: 2574180442), in which there was no che or che-like gene cluster, the che and che-like gene clusters of the other 10 Comamonas genomes were shown. GenbBank IDs are BCNR01000016.1 (C. terrigena); CP021455.1 (C. serinivorans); AXVM00000000.1 (C. badia); BCNT01000000.1 (C. terrae); AUCQ01000000.1 (C. composti); CP001220.2 (C. testosteroni); CP020121.1 (C. kerstersii); AWTO01000000.1 (C. thiooxydans); BBJX01000000.1 (C. granuli); and CP016603.1 (C. aquatica). The lengths of rectangles are independent of the lengths of gene sequences. 


\section{Summary and Perspective}

The knowledge of bacterial chemotaxis toward aromatic compounds is of fundamental importance to understanding how bacteria adapt and survive in environments, and is also important for the development of biosensors for the detection of aromatic compounds and to improve bioremediation of aromatic-polluted environments. As an emerging environmental model organism, not only the ability of $C$. testosteroni to degrade aromatic compounds, but also its chemotaxis, has attracted more and more attention. Studies with $C$. testosteroni have revealed that chemotaxis towards aromatic compounds can be triggered via sensing their intermediate metabolites of Kreb's cycle [36,37], and also provided the first evidence that chemoreceptor MCP2901 binds directly to aromatic compounds [38]. Chemotaxis helps bacteria to find aromatic compounds, and the degradation of aromatic compounds can produce more chemoeffectors to attract bacteria. A positive feedback loop is generated from this process. In addition, studies with $C$. testosteroni has also revealed novel functions of che-like clusters and new chemotactic proteins [48].

Considering the diversity of aromatic compounds and of the putative bacterial chemoreceptors, there are more "unknowns" than "knowns". For examples, how chemoreceptors coordinate themselves for chemotaxis and other behaviors, and how the signals generated from chemoreceptors can be transmitted downstream, should be the focus of future research. In addition, what the functions are of novel che-like gene clusters, such as clusters in C. granuli and C. aquatic, is also an interesting question. Answers to these questions will not only improve our understanding of chemotaxis with $C$. testosteroni and other Comamonas species, but will also provide more insight into our understanding of sense and transduction of signals among chemotactic microorganisms.

Funding: This work was supported by grants from the National Natural Science Foundation of China (31230003 and 31861133002 to S.-J.L.)

Acknowledgments: The authors appreciate of constructive comments and stimulations on this review from Tino Krell at the Estación Experimental del Zaidín, Spain.

Conflicts of Interest: The authors declare no conflict of interest.

\section{References}

1. Gibson, J.; S Harwood, C. Metabolic diversity in aromatic compound utilization by anaerobic microbes. Annu. Rev. Microbiol. 2002, 56, 345-369. [CrossRef]

2. Fuchs, G.; Boll, M.; Heider, J. Microbial degradation of aromatic compounds-from one strategy to four. Nat. Rev. Microbiol. 2011, 9, 803-816. [CrossRef]

3. Keith, L.H.; Telliard, W.A. Priority pollutants I-a perspective view. Environ. Sci. Technol. 1979, 13, 416-423. [CrossRef]

4. Buchanan-Kilbey, G.; Djumpah, J.; Papadopoulou, M.V.; Bloomer, W.; Hu, L.; Wilkinson, S.R.; Ashworth, R. Evaluating the developmental toxicity of trypanocidal nitroaromatic compounds on zebrafish. Acta Trop 2013, 128, 701-705. [CrossRef] [PubMed]

5. Purohit, V.; Basu, A.K. Mutagenicity of nitroaromatic compounds. Chem. Res. Toxicol. 2000, 13, 673-692. [CrossRef]

6. Haritash, A.K.; Kaushik, C.P. Biodegradation aspects of polycyclic aromatic hydrocarbons (PAHs): A review. J. Hazard. Mater. 2009, 169, 1-15. [CrossRef]

7. Yuan, S.Y.; Chang, J.S.; Yen, J.H.; Chang, B.V. Biodegradation of phenanthrene in river sediment. Chemosphere 2001, 43, 273-278. [CrossRef]

8. Gordillo, F.; Chavez, F.P.; Jerez, C.A. Motility and chemotaxis of Pseudomonas sp. B4 towards polychlorobiphenyls and chlorobenzoates. FEMS Microbiol. Ecol. 2007, 60, 322-328. [CrossRef] [PubMed]

9. Krell, T.; Lacal, J.; Guazzaroni, M.E.; Busch, A.; Silva-Jimenez, H.; Fillet, S.; Reyes-Darias, J.A.; Munoz-Martinez, F.; Rico-Jimenez, M.; Garcia-Fontana, C.; et al. Responses of Pseudomonas putida to toxic aromatic carbon sources. J. Biotechnol. 2012, 160, 25-32. [CrossRef] 
10. Tremaroli, V.; Vacchi Suzzi, C.; Fedi, S.; Ceri, H.; Zannoni, D.; Turner, R.J. Tolerance of Pseudomonas pseudoalcaligenes KF707 to metals, polychlorobiphenyls and chlorobenzoates: Effects on chemotaxis-, biofilmand planktonic-grown cells. FEMS Microbiol. Ecol. 2010, 74, 291-301. [CrossRef] [PubMed]

11. Lacal, J.; Reyes-Darias, J.A.; Garcia-Fontana, C.; Ramos, J.L.; Krell, T. Tactic responses to pollutants and their potential to increase biodegradation efficiency. J. Appl. Microbiol. 2013, 114, 923-933. [CrossRef]

12. Marx, R.B.; Aitken, M.D. Bacterial chemotaxis enhances naphthalene degradation in a heterogeneous aqueous system. Environ. Sci. Technol. 2000, 34, 3379-3383. [CrossRef]

13. Krell, T.; Lacal, J.; Reyes-Darias, J.A.; Jimenez-Sanchez, C.; Sungthong, R.; Ortega-Calvo, J.J. Bioavailability of pollutants and chemotaxis. Curr. Opin. Biotechnol. 2013, 24, 451-456. [CrossRef] [PubMed]

14. Parales, R.E.; Harwood, C.S. Bacterial chemotaxis to pollutants and plant-derived aromatic molecules. Curr. Opin. Microbiol. 2002, 5, 266-273. [CrossRef]

15. Bi, S.; Sourjik, V. Stimulus sensing and signal processing in bacterial chemotaxis. Curr. Opin. Microbiol. 2018, 45, 22-29. [CrossRef] [PubMed]

16. Wong-Ng, J.; Celani, A.; Vergassola, M. Exploring the function of bacterial chemotaxis. Curr. Opin. Microbiol. 2018, 45, 16-21. [CrossRef]

17. Sampedro, I.; Parales, R.E.; Krell, T.; Hill, J.E. Pseudomonas chemotaxis. Fems. Microbiol. Rev. 2015, 39, 17-46.

18. Hatayama, K. Comamonas humi sp. nov. isolated from soil. Int. J. Syst. Evol. Microbiol. 2014, 64, 3976-3982. [CrossRef]

19. Subhash, Y.; Bang, J.J.; You, T.H.; Lee, S.S. Description of Comamonas sediminis sp. nov. isolated from lagoon sediments. Int. J. Syst. Evol. Microbiol. 2016, 66, 2735-2739. [CrossRef]

20. Kampfer, P.; Busse, H.J.; Baars, S.; Wilharm, G.; Glaeser, S.P. Comamonas aquatilis sp. nov. isolated from a garden pond. Int. J. Syst. Evol. Microbiol. 2018, 68, 1210-1214. [CrossRef]

21. Chen, I.A.; Chu, K.; Palaniappan, K.; Pillay, M.; Ratner, A.; Huang, J.; Huntemann, M.; Varghese, N.; White, J.R.; Seshadri, R.; et al. IMG/M v.5.0: An integrated data management and comparative analysis system for microbial genomes and microbiomes. Nucleic Acids Res. 2019, 47, D666-D677. [CrossRef]

22. Liu, L.; Zhu, W.T.; Cao, Z.; Xu, B.A.; Wang, G.J.; Luo, M.Z. High correlation between genotypes and phenotypes of environmental bacteria Comamonas testosteroni strains. BMC Genomics 2015, 16. [CrossRef] [PubMed]

23. Kertesz, M.A. Riding the sulfur cycle-metabolism of sulfonates and sulfate esters in gram-negative bacteria. Fems Microbiol Rev. 2000, 24, 135-175. [PubMed]

24. Zhu, W.; Wang, C.; Hill, J.; He, Y.; Tao, B.; Mao, Z.; Wu, W. A missing link in the estuarine nitrogen cycle: Coupled nitrification-denitrification mediated by suspended particulate matter. Sci Rep. 2018, 8, 2282. [CrossRef]

25. Arrigo, K.R. Marine microorganisms and global nutrient cycles. Nature 2005, 437, 349-355. [CrossRef] [PubMed]

26. Watanabe, K.; Futamata, H.; Harayama, S. Understanding the diversity in catabolic potential of microorganisms for the development of bioremediation strategies. Antonie Van Leeuwenhoek 2002, 81, 655-663. [CrossRef] [PubMed]

27. Watanabe, K. Linking genetics, physiology and ecology: An interdisciplinary approach for advancing bioremediation. J. Biosci. Bioeng. 2002, 94, 557-562. [CrossRef]

28. Andreoni, V.; Gianfreda, L. Bioremediation and monitoring of aromatic-polluted habitats. Appl. Microbiol. Biotechnol. 2007, 76, 287-308. [CrossRef] [PubMed]

29. Wu, J.F.; Sun, C.W.; Jiang, C.Y.; Liu, Z.P.; Liu, S.J. A novel 2-aminophenol 1,6-dioxygenase involved in the degradation of p-chloronitrobenzene by Comamonas strain CNB-1: Purification, properties, genetic cloning and expression in Escherichia coli. Arch. Microbiol. 2005, 183, 1-8. [CrossRef]

30. Liu, L.; Jiang, C.Y.; Liu, X.Y.; Wu, J.F.; Han, J.G.; Liu, S.J. Plant-microbe association for rhizoremediation of chloronitroaromatic pollutants with Comamonas sp. strain CNB-1. Environ. Microbiol. 2007, 9, 465-473. [CrossRef]

31. Ma, Y.F.; Wu, J.F.; Wang, S.Y.; Jiang, C.Y.; Zhang, Y.; Qi, S.W.; Liu, L.; Zhao, G.P.; Liu, S.J. Nucleotide sequence of plasmid pCNB1 from Comamonas strain CNB-1 reveals novel genetic organization and evolution for 4-chloronitrobenzene degradation. Appl. Environ. Microbiol. 2007, 73, 4477-4483. [CrossRef] 
32. Wu, J.F.; Jiang, C.Y.; Wang, B.J.; Ma, Y.F.; Liu, Z.P.; Liu, S.J. Novel partial reductive pathway for 4-chloronitrobenzene and nitrobenzene degradation in Comamonas sp. strain CNB-1. Appl. Environ. Microbiol. 2006, 72, 1759-1765. [CrossRef] [PubMed]

33. Ma, Y.F.; Zhang, Y.; Zhang, J.Y.; Chen, D.W.; Zhu, Y.; Zheng, H.; Wang, S.Y.; Jiang, C.Y.; Zhao, G.P.; Liu, S.J. The complete genome of Comamonas testosteroni reveals its genetic adaptations to changing environments. Appl. Environ. Microbiol. 2009, 75, 6812-6819. [CrossRef]

34. Alexandre, G.; Greer-Phillips, S.; Zhulin, I.B. Ecological role of energy taxis in microorganisms. Fems. Microbiol. Rev. 2004, 28, 113-126. [CrossRef] [PubMed]

35. Rabinovitch-Deere, C.A.; Parales, R.E. Three types of taxis used in the response of Acidovorax sp. strain JS42 to 2-nitrotoluene. Appl. Environ. Microbiol. 2012, 78, 2306-2315. [CrossRef]

36. Ni, B.; Huang, Z.; Fan, Z.; Jiang, C.Y.; Liu, S.J. Comamonas testosteroni uses a chemoreceptor for tricarboxylic acid cycle intermediates to trigger chemotactic responses towards aromatic compounds. Mol. Microbiol. 2013, 90, 813-823. [CrossRef] [PubMed]

37. Ni, B.; Huang, Z.; Wu, Y.F.; Fan, Z.; Jiang, C.Y.; Liu, S.J. A novel chemoreceptor MCP2983 from Comamonas testosteroni specifically binds to cis-aconitate and triggers chemotaxis towards diverse organic compounds. Appl. Microbiol. Biotechnol. 2015, 99, 2773-2781. [CrossRef]

38. Huang, Z.; Ni, B.; Jiang, C.Y.; Wu, Y.F.; He, Y.Z.; Parales, R.E.; Liu, S.J. Direct sensing and signal transduction during bacterial chemotaxis toward aromatic compounds in Comamonas testosteroni. Mol. Microbiol. 2016, 101, 224-237. [CrossRef] [PubMed]

39. Gohler, A.; Xiong, G.; Paulsen, S.; Trentmann, G.; Maser, E. Testosterone-inducible regulator is a kinase that drives steroid sensing and metabolism in Comamonas testosteroni. J. Biol. Chem. 2008, 283, 17380-17390. [CrossRef]

40. Welch, M.; Oosawa, K.; Aizawa, S.; Eisenbach, M. Phosphorylation-dependent binding of a signal molecule to the flagellar switch of bacteria. Proc. Natl. Acad. Sci. USA 1993, 90, 8787-8791. [CrossRef]

41. Blat, Y.; Eisenbach, M. Phosphorylation-dependent binding of the chemotaxis signal molecule CheY to its phosphatase, CheZ. Biochemistry 1994, 33, 902-906. [CrossRef]

42. Springer, W.R.; Koshland, D.E., Jr. Identification of a protein methyltransferase as the cheR gene product in the bacterial sensing system. Proc. Natl. Acad. Sci. USA 1977, 74, 533-537. [CrossRef]

43. Kehry, M.R.; Bond, M.W.; Hunkapiller, M.W.; Dahlquist, F.W. Enzymatic Deamidation of methyl-accepting chemotaxis proteins in Escherichia coli catalyzed by the cheB Gene product. Proc. Natl. Acad. Sci. USA 1983, 80, 3599-3603. [CrossRef]

44. Ulrich, L.E.; Zhulin, I.B. The MiST2 database: A comprehensive genomics resource on microbial signal transduction. Nucleic Acids Res. 2010, 38, D401-D407. [CrossRef] [PubMed]

45. Alexander, R.P.; Zhulin, I.B. Evolutionary genomics reveals conserved structural determinants of signaling and adaptation in microbial chemoreceptors. Proc. Natl. Acad. Sci. USA 2007, 104, 2885-2890. [CrossRef] [PubMed]

46. Wuichet, K.; Zhulin, I.B. Origins and diversification of a complex signal transduction system in prokaryotes. Sci. Signal. 2010, 3, ra50. [CrossRef] [PubMed]

47. Ortega, D.R.; Fleetwood, A.D.; Krell, T.; Harwood, C.S.; Jensen, G.J.; Zhulin, I.B. Assigning chemoreceptors to chemosensory pathways in Pseudomonas aeruginosa. Proc. Natl. Acad. Sci. USA 2017, 114, 12809-12814. [CrossRef]

48. Huang, Z.; Wang, Y.H.; Zhu, H.Z.; Andrianova, E.P.; Jiang, C.Y.; Li, D.; Ma, L.; Feng, J.; Liu, Z.P.; Xiang, H.; et al. Cross talk between chemosensory pathways that modulate chemotaxis and biofilm formation. MBio 2019, 10, e02876-18. [CrossRef]

49. Adebali, O.; Ortega, D.R.; Zhulin, I.B. CDvist: A webserver for identification and visualization of conserved domains in protein sequences. Bioinformatics 2015, 31, 1475-1477. [CrossRef] [PubMed]

50. Wuichet, K.; Alexander, R.P.; Zhulin, I.B. Comparative genomic and protein sequence analyses of a complex system controlling bacterial chemotaxis. Methods Enzymol. 2007, 422, 1-31.

51. Lacal, J.; Garcia-Fontana, C.; Munoz-Martinez, F.; Ramos, J.L.; Krell, T. Sensing of environmental signals: Classification of chemoreceptors according to the size of their ligand binding regions. Environ. Microbiol. 2010, 12, 2873-2884. [CrossRef] [PubMed]

52. Ortega, A.; Zhulin, I.B.; Krell, T. Sensory repertoire of bacterial chemoreceptors. Microbiol. Mol. Biol. Rev. 2017, 81, e00033-17. [CrossRef] [PubMed] 
53. Martin-Mora, D.; Fernandez, M.; Velando, F.; Ortega, A.; Gavira, J.A.; Matilla, M.A.; Krell, T. Functional annotation of bacterial signal transduction systems: Progress and challenges. Int. J. Mol. Sci. 2018, $19,3755$. [CrossRef]

54. Corral-Lugo, A.; Matilla, M.A.; Martin-Mora, D.; Silva Jimenez, H.; Mesa Torres, N.; Kato, J.; Hida, A.; Oku, S.; Conejero-Muriel, M.; Gavira, J.A.; et al. High-affinity chemotaxis to histamine mediated by the TlpQ chemoreceptor of the human pathogen Pseudomonas aeruginosa. MBio 2018, 9, e01894-18. [CrossRef]

55. Hida, A.; Tajima, T.; Kato, J. Two citrate chemoreceptors involved in chemotaxis to citrate and/or citrate-metal complexes in Ralstonia pseudosolanacearum. J. Biosci. Bioeng. 2019, 127, 169-175. [CrossRef]

56. Feng, H.; Zhang, N.; Du, W.; Zhang, H.; Liu, Y.; Fu, R.; Shao, J.; Zhang, G.; Shen, Q.; Zhang, R. Identification of chemotaxis compounds in root exudates and their sensing chemoreceptors in plant-growth-promoting rhizobacteria Bacillus amyloliquefaciens SQR9. Mol. Plant. Microbe Interact. 2018, 31, 995-1005. [CrossRef]

57. Paul, D.; Singh, R.; Jain, R.K. Chemotaxis of Ralstonia sp. SJ98 towards p-nitrophenol in soil. Environ. Microbiol. 2006, 8, 1797-1804. [CrossRef]

58. Hawkins, A.C.; Harwood, C.S. Chemotaxis of Ralstonia eutropha JMP134(pJP4) to the herbicide 2,4-dichlorophenoxyacetate. Appl. Environ. Microbiol. 2002, 68, 968-972. [CrossRef]

59. Parke, D.; Ornston, L.N.; Nester, E.W. Chemotaxis to plant phenolic inducers of virulence genes is constitutively expressed in the absence of the Ti-plasmid in Agrobacterium tumefaciens. J. Bacteriol. 1987, 169, 5336-5338. [CrossRef] [PubMed]

60. Lopez-de-Victoria, G.; Lovell, C.R. Chemotaxis of Azospirillum species to aromatic compounds. Appl. Environ. Microbiol. 1993, 59, 2951-2955.

61. Parke, D.; Rivelli, M.; Ornston, L.N. Chemotaxis to aromatic and hydroaromatic acids: Comparison of Bradyrhizobium japonicum and Rhizobium trifolii. J. Bacteriol. 1985, 163, 417-422.

62. Pandey, G.; Jain, R.K. Bacterial chemotaxis toward environmental pollutants: Role in bioremediation. Appl. Environ. Microbiol. 2002, 68, 5789-5795. [CrossRef]

63. Luu, R.A.; Schneider, B.J.; Ho, C.C.; Nesteryuk, V.; Ngwesse, S.E.; Liu, X.X.; Parales, J.V.; Ditty, J.L.; Parales, R.E. Taxis of Pseudomonas putida F1 toward phenylacetic acid is mediated by the energy taxis receptor Aer2. Appl. Environ. Microbiol. 2013, 79, 2416-2423. [CrossRef]

64. Sarand, I.; Osterberg, S.; Holmqvist, S.; Holmfeldt, P.; Skarfstad, E.; Parales, R.E.; Shingler, V. Metabolism-dependent taxis towards (methyl)phenols is coupled through the most abundant of three polar localized Aer-like proteins of Pseudomonas putida. Environ. Microbiol. 2008, 10, 1320-1334. [CrossRef]

65. Key, J.; Hefti, M.; Purcell, E.B.; Moffat, K. Structure of the redox sensor domain of Azotobacter vinelandii NifL at atomic resolution: Signaling, dimerization, and mechanism. Biochemistry 2007, 46, 3614-3623. [CrossRef]

66. Martin-Mora, D.; Ortega, A.; Reyes-Darias, J.A.; Garcia, V.; Lopez-Farfan, D.; Matilla, M.A.; Krell, T. Identification of a chemoreceptor in Pseudomonas aeruginosa that specifically mediates chemotaxis toward alpha-ketoglutarate. Front. Microbiol. 2016, 7, 1937. [CrossRef]

67. Lacal, J.; Alfonso, C.; Liu, X.; Parales, R.E.; Morel, B.; Conejero-Lara, F.; Rivas, G.; Duque, E.; Ramos, J.L.; Krell, T. Identification of a chemoreceptor for tricarboxylic acid cycle intermediates: Differential chemotactic response towards receptor ligands. J. Biol. Chem. 2010, 285, 23126-23136. [CrossRef]

68. Yamamoto, K.; Imae, Y. Cloning and characterization of the Salmonella typhimurium specific chemoreceptor Tcp for taxis to citrate and from phenol. Proc. Natl. Acad. Sci. USA 1993, 90, 217-221. [CrossRef]

69. Grimm, A.C.; Harwood, C.S. Chemotaxis of Pseudomonas spp. to the polyaromatic hydrocarbon naphthalene. Appl. Environ. Microbiol. 1997, 63, 4111-4115.

70. Grimm, A.C.; Harwood, C.S. NahY, a catabolic plasmid-encoded receptor required for chemotaxis of Pseudomonas putida to the aromatic hydrocarbon naphthalene. J. Bacteriol. 1999, 181, 3310-3316.

71. Iwaki,H.; Muraki, T.; Ishihara, S.; Hasegawa, Y.; Rankin, K.N.; Sulea, T.; Boyd, J.; Lau, P.C. Characterization of a pseudomonad 2-nitrobenzoate nitroreductase and its catabolic pathway-associated 2-hydroxylaminobenzoate mutase and a chemoreceptor involved in 2-nitrobenzoate chemotaxis. J. Bacteriol. 2007, 189, 3502-3514. [CrossRef]

72. Lacal, J.; Munoz-Martinez, F.; Reyes-Darias, J.A.; Duque, E.; Matilla, M.; Segura, A.; Calvo, J.J.; Jimenez-Sanchez, C.; Krell, T.; Ramos, J.L. Bacterial chemotaxis towards aromatic hydrocarbons in Pseudomonas. Environ. Microbiol. 2011, 13, 1733-1744. [CrossRef] [PubMed] 
73. Vangnai, A.S.; Takeuchi, K.; Oku, S.; Kataoka, N.; Nitisakulkan, T.; Tajima, T.; Kato, J. Identification of CtpL as a chromosomally encoded chemoreceptor for 4-chloroaniline and catechol in Pseudomonas aeruginosa PAO1. Appl. Environ. Microbiol. 2013, 79, 7241-7248. [CrossRef]

74. Garcia, V.; Reyes-Darias, J.A.; Martin-Mora, D.; Morel, B.; Matilla, M.A.; Krell, T. Identification of a chemoreceptor for C2 and C3 carboxylic acids. Appl. Environ. Microbiol. 2015, 81, 5449-5457. [CrossRef]

75. Fernandez, M.; Matilla, M.A.; Ortega, A.; Krell, T. Metabolic value chemoattractants are preferentially recognized at broad ligand range chemoreceptor of Pseudomonas putida KT2440. Front. Microbiol. 2017, 8, 990. [CrossRef]

76. Wadhams, G.H.; Armitage, J.P. Making sense of it all: Bacterial chemotaxis. Nat. Rev. Mol. Cell Biol. 2004, 5, 1024-1037. [CrossRef]

77. Sourjik, V.; Armitage, J.P. Spatial organization in bacterial chemotaxis. EMBO J. 2010, 29, $2724-2733$. [CrossRef]

78. Krell, T.; Lacal, J.; Munoz-Martinez, F.; Reyes-Darias, J.A.; Cadirci, B.H.; Garcia-Fontana, C.; Ramos, J.L. Diversity at its best: Bacterial taxis. Environ. Microbiol. 2011, 13, 1115-1124. [CrossRef]

79. Muff, T.J.; Ordal, G.W. The diverse CheC-type phosphatases: Chemotaxis and beyond. Mol. Microbiol. 2008, 70, 1054-1061. [CrossRef]

80. Alexander, R.P.; Lowenthal, A.C.; Harshey, R.M.; Ottemann, K.M. CheV: CheW-like coupling proteins at the core of the chemotaxis signaling network. Trends Microbiol. 2010, 18, 494-503. [CrossRef] [PubMed]

81. Kirby, J.R. Chemotaxis-like regulatory systems: Unique roles in diverse bacteria. Annu. Rev. Microbiol. 2009, 63, 45-59. [CrossRef] [PubMed]

82. Porter, S.L.; Wadhams, G.H.; Armitage, J.P. Signal processing in complex chemotaxis pathways. Nat. Rev. Microbiol. 2011, 9, 153-165. [CrossRef]

83. Mukherjee, T.; Kumar, D.; Burriss, N.; Xie, Z.; Alexandre, G. Azospirillum brasilense chemotaxis depends on two signaling pathways regulating distinct motility parameters. J. Bacteriol. 2016, 198, 1764-1772. [CrossRef]

84. Whitchurch, C.B.; Leech, A.J.; Young, M.D.; Kennedy, D.; Sargent, J.L.; Bertrand, J.J.; Semmler, A.B.; Mellick, A.S.; Martin, P.R.; Alm, R.A.; et al. Characterization of a complex chemosensory signal transduction system which controls twitching motility in Pseudomonas aeruginosa. Mol. Microbiol. 2004, 52, 873-893. [CrossRef] [PubMed]

85. Hickman, J.W.; Tifrea, D.F.; Harwood, C.S. A chemosensory system that regulates biofilm formation through modulation of cyclic diguanylate levels. Proc. Natl. Acad. Sci. USA 2005, 102, 14422-14427. [CrossRef]

86. Berleman, J.E.; Bauer, C.E. Involvement of a Che-like signal transduction cascade in regulating cyst cell development in Rhodospirillum centenum. Mol. Microbiol. 2005, 56, 1457-1466. [CrossRef] [PubMed]

87. Berleman, J.E.; Bauer, C.E. A che-like signal transduction cascade involved in controlling flagella biosynthesis in Rhodospirillum centenum. Mol. Microbiol. 2005, 55, 1390-1402. [CrossRef] 